\title{
Dynamic and Geological-Ecological Spatial Planning Approach in Hot Mud Volcano Affected Area in Porong-Sidoarjo
}

\author{
Haryo Sulistyarso ${ }^{1}$
}

\begin{abstract}
${ }^{3}$ Abstract-By May $29^{\text {th }} 2006$ with an average hot mud volcano volume of $100,000 \mathrm{~m}^{3} / \mathrm{per}$ day, disasters on well kick (i.e. Lapindo Brantas Ltd.) in Banjar Panji 1 drilling well have deviated the Spatial Planning of Sidoarjo's Regency for 20032013. Regional Development Concept that is aimed at developing triangle growth pole model on SIBORIAN (SIdoarjo-JaBOn-KRIaAN) could not be implemented. This planning cannot be applied due to environmental imbalance to sub district of Porong that was damaged by hot mud volcano. In order to anticipate deviations of the Regional and Spatial Planning of Sidoarjo Regency for 2003-2013, a review on regional planning and dynamic implementation as well as Spatial Planning Concept based on geologicalecological condition are required, especially the regions affected by well kick disaster. The spatial analysis is based on the geological and ecological condition by using an overlay technique using several maps of hot mud volcano affected areas. In this case, dynamic implementation is formulated to the responsiblity plan that can happen at any time because of uncertain ending of the hot mud volcano eruption disaster in Porong. The hot mud volcano affected areas in the Sidoarjo's Spatial Planning 2009-2029 have been decided as a geologic protected zone. The result of this research is scenarios of spatial planning for the affected area (short term, medium term and long term spatial planning scenarios).
\end{abstract}

Keywords-Spatial planning, hot mud volcano, SIBORIAN growth pole, geologic protected zone

\section{INTRODUCTION}

$\mathrm{S}_{\mathrm{i} i}$ idoarjo Regency, covering all natural resources including land, sea, air space, andthe underneath resources as well, need to be controlled sustainably for the greatest benefits for the people, this is in accordance with the mandate stated in article 33 paragraph (3) of the Constitution of the Republic of Indonesia 1945, and Regulations Number 26, 2007 about Spatial Planning. Geographically, Sidoarjo Regency is situated in strategic location, both for regional and national interests. From the point of its ecosystem, the nature state of Sidoarjo Regency is very typical to the 'Delta' region with the weathers, seasons and tropical climates that are all valuable assets in terms of their great potential and natural resources.

\footnotetext{
${ }^{1}$ Haryo Sulistyarso is with Department of Urban and Regional Planning, FTSP. Institut Teknologi Sepuluh Nopember, Surabaya, 60111, Indonesia. E-mail: tenggilis44@gmail.com.
}

In East Java Province Spatial Planning 2005 - 2025 (Peraturan Daerah Propinsi Jawa Timur Nomor 2 Tahun 2006 Tentang Rencana Tata Ruang Propinsi Jawa Timur 2005-2025), Sidoarjo Regency is classified as one of which entering the Regional Development Unit of Gerbangkertosusila Plus (i.e. Gresik, Bangkalan, Mojokerto, Surabaya, Sidoarjo, Lamongan Plus Pasuruan Regency). Porong hot mud volcano disaster happened in May $29^{\text {th }} 2006$ has made Regional Spatial Planning need to be revisited, not to mention the areas of Regional Development Unit of Gerbangkertasusila and Sidoarjo Regency as well as the province of East Java. The impact of the hot mud volcano in Porong has significantly influenced the spatial structure of Sidoarjo Regency Spatial Planning 2003-2013 (Peraturan Daerah Kabupaten Sidoarjo Nomor 16 Tahun 2003 Tentang Rencana Tata Ruang Wilayah Kabupaten Sidoarjo 2003 - 2013).

The geographical, natural or ecosystem balances of Sidoarjo Regency which have formerly existed have been interfered by the eruption of hot water and mud in May $29^{\text {th }} 2006$, in Renokenongo village of Porong district. The volume of hot mud volcano flow subsequently increases volume up to the estimated volume, $1,000 \mathrm{~m}^{3}$ per day (PSKB,2009). The hot mud volcano flow continues asscending until today, and remains damaging the environment and the ecosystem around the eruption sites. Besides the environmental damage, other arising problems are the disruption of goods and services distributions due to disconnected Porong toll road and the spatial structural changes that have been specified in Regulations of East Java Province Spatial Planning 2005-2025 and Sidoarjo Regency Spatial Planning 20032013.

Previous related studies on similar issues of the hot mud volcano have been conducted by other researchers, such as Karr (2008) and Rambudi (2007); especially those concerning the locations of hot mud volcano in Porong, and some related to geological problems as it has been done by Widodo (2008) and environmental problems by Tuti (2008). This present research concerns with spatial issues, particularly the affected sites of the hot mud volcano, with synthesizing results of geological and environmental research conducted previously by PSKB-ITS (2009).

Based on data collecting up to April 2009, the affected areasare approximately 740 hectares (Sidoarjo Regency Spatial Planning 2009-2029). The main problem in the areas affected by the hot mud volcano in Porong is the absence of affirmation statement from the academicians and experts (especially from Geologist) to show, or to forecast-at least, a nearly concise time when the hot mud volcano disaster would have been over. This has always been a polemic and debate among many geologists, as a consequence, the uncertainties have made Spatial Plann- 
ing of Sidoarjo Regency and the affected areas of hot mud volcano flow find difficulties to make decisions.

\section{THEORIES}

This research is carried out under the bases of spatial theory particularly those concerning with the risk probability in the hot mud volcano affected areas in Porong. One of the important things according to this theory is a

measuring the empirical probability of a failure using past performance data, experimental assessment and expert judgment. This analytical method is used for spatial analysis by means of an overlay technique of several maps relating to the factors that influence the hazard due to the hot mud volcano flow susceptibility (in this research that geological and ecological factors).

The results of this analysis is based on the susceptibility of hot mud volcano flow affected area (spatial review), which is transformed into the spatial boundaries. Otherwise, in context of land use planning, probabilistic risk assessment has to be analyzed and calculated precisely, such as examination of crucial environmental factors that might either precipitate or exacerbate a technical failure (geologic fault lines, land subsidence).

\section{METHOD}

The general objective of this present study is to help the thinking and seeking of the optimal solution within the framework of Sidoarjo Regency Spatial Planning Revision from 2009 to 2029 associated with the hot mud volcano in Porong. Meanwhile, the particular objective is to find a suitable concept of spatial structure in the hot mud volcano affected areas with spatial, the geological and ecological thinking. Therefore, to come the above solution,the research method employed in this present study is the implementation of combination between spatial analysis and overlay method focusing on hot mud volcano flow prediction. Specifically speaking, the spatial analysis employed in this present study is based on the geological and ecological condition by means of an overlay technique using several maps of hot mud volcano affected areas.

\section{RESULT AND DISCUSSIONS}

Both, the areas affected and to be affected as well, extend from Tanggulangin Districs to Porong, including several villages: Ketapang, Siring Barat, Jatirejo, Kedung Bendo, Siring Timur, Mindi, Kedung Cangkring, Reno Kenongo, Besuki, Pejarakan and Perumtas The affected area is estimated about 740 hectares wide (Sidoarjo Regency Spatial Planning 2009-2029). The estimation of the affected area can be even greater if the dikes mudguard is no longer able to accommodate the surge and pressure of mud that occur over topping, and hence the mud would runoff over some other villages. External condition of the disasters occurred in the center of eruption, Porong District, east of the well drilling locations, Banjar Panji 1 (approximately 150 meters from the drilling location of Banjar Panji 1), with coordinates of 112'71" East longitude and 7'52" South latitude. Hot mud volcano area is adjacent to the border between the territories of Sidoarjo Regency and Pasuruan Regency (Fig. 1 and 2).

\section{A. Conditions of The Area of The Hot Mud Volcano}

The condition of the regions before and after the hot mud volcano to the current condition (December 2009) is generally described as follows.

\section{Prior to The Hot Mud Volcano Flow}

a. Topography: based on the data, Sidoarjo in figures in 2008, the height of the topography of the Tanggulangin and Porong districts is 4.00 meters above main sea level (msl) and Jabon is 3.00 meters above main sea level (msl) with a slope of 0 to $2 \%$. This land elevation shows that the water flows toward east or to Madura Strait

b. Soil Type: The type of soil in the districts of Porong, Jabon and Tanggulangin consists of gray alluvial soil and gray yellowish brown alluvial composition. These soil types show that lands in these districts are fertile.

c. Climatology: based on the data, Sidoarjo in figures in 2008, the highest temperature in Porong district, Tanggulangin and Jabon reaches $35^{\circ} \mathrm{C}$ and $20^{\circ} \mathrm{C}$ is the lowest. Meanwhile, the average rainfall in one year reaches 1000 to $2500 \mathrm{~mm}$. Rainfall in Porong District reaches $1279 \mathrm{~mm} / \mathrm{year}$ with 66 rainy days in a year. These conditions have provided such great potential for agricultural activities. Fertile soil in the Porong Districts before the hot mud blast was dominated by technical irrigation system (covering 1165 ha area, or $39.06 \%$ of the Registered Porong district land of 2982.30 hectares) and agriculture.

\section{After The Eruption of Hot Mud Volcano}

The eruption area conditions, which were previously utilized for technical irrigation of rice field, have changed gradually since the torrent of hot mud and water above the surface in May $29^{\text {th }}, 2006$. The eruption of hot mud and water triggered by the lifting of the drilling pipe, at that time reached the drilling depth of approximately 2700 meters, (PSKB ,2009) which resulted in well-kick, slowly but surely increased and widespread negative effects. Until November $10^{\text {th }} 2009$, field data showed that the affected area was around 740 hectares, covering 3 districts (Porong, Tanggulangin dan Jabon) and includes 11 villages (Ketapang, Siring Barat, Jatirejo, Kedung Bendo, Siring Timur, Mindi, Kedung Cangkring, Reno Kenongo, Besuki, Pejarakan dan Kebo Guyang)(Sidoarjo Regency Spatial Plannig 2009-2029).

The vast area, which is affected significantly, alters the structure and spatial pattern in the Sidoarjo Regency as it has been stated in Sidoarjo Regency Spatial Planning and ratified by regulation (Peraturan Daerah Kabupaten Sidoarjo Nomor 16 Tahun 2003 Tentang Rencana Tata Ruang Kabupaten Sidoarjo Tahun 2003 - 2013). The influence of the disaster is not only changing land use in the affected region, but also giving major impacts on various things, such as:

a. Technical Impacts:

$i$. Dissolution of the network infrastructure (toll road Sidoarjo-Gempol, clean water network of Umbulan, high voltage electricity networks).

ii. Disruption of the railway transportation modes Surabaya - Malang / Pasuruan and vehicle transportation modes through a primary arterial road, which affects the distribution of goods and services. 
iii. Disruption of the environmental balance (water pollution, air and soil)

b. Non technical impact (social, economic, cultural):

$i$. Social upheaval and destruction of social network system in the rural community life are affected and must be evacuated to a temporary location.

ii. Unsolved problem of land compensation completion has prolonged the community restlessness.

iii. Damage disruption on rural economic activities in the affected villages.

\section{B. The Influence of Hot Mud Volcano on Spatial and Ecosystem}

In terms of spatial planning, the greatest impact of the blasting hot mud volcano is the interference to the concept of Regional Development stipulated in Sidoarjo Regency such as on Sidoarjo Regency Spatial Planning 2003 - 2013, which is based on the concept of dynamic growth set forth in the concept of 'triangle spatial development concept' based on the 3-pole sub-region development growth, namely: District Sidoarjo - Jabon Krian, known as SIBORIAN growth pole triangle development concept [9]. Because of the hot mudflow in Porong, the dynamic growth of the previous plan occured in the triangle area development is difficult or evenin practice. In addition, the affected area has reached 740 hectares wide up to November 2009 (approximately $1.03 \%$ of the total land area of Sidoarjo of 71,424.50 hectares); it means that there should have been any sites designated for resettlement of communities.

In terms of ecosystems, the results of research conducted by an ITS team in 2008 [24], at some point, show in the sample containing substances that exceed limits or the standard of quality, which is determined by East Java Governor Regulation [22] on Ambient Air Quality Standard and Emission of Not-Moving-Sources in East Java (Baku Mutu Udara Ambien dan Emisi Sumber Tidak Bergerak di Jawa Timur). The team has identified the air pollution caused by the hot mud volcano flow using these parameters: $\mathrm{CO}, \mathrm{SO}_{3}, \mathrm{NO}_{2}, \mathrm{O}_{3}$, $\mathrm{Pb}, \mathrm{H}_{2} \mathrm{~S}, \mathrm{NH}_{3}, \mathrm{HC}\left(\mathrm{CH}_{4}\right)$ and dust by measuring the wind direction, speed, temperature and humidity. From the ambient air samples, it shows that HC quantities measured with $\mathrm{CH}_{4}$ (methane) exceed the threshold level, as shown in Table 1.

Moreover, the test results with some other parameters also show the numbers well above the standard quality (Siring Barat village: 0,116 ppm $\mathrm{NO}_{2}$ and Dust 0,351 $\mathrm{ppm}$ ). Based on the Governor of East Java Regulation, these figures have exceeded the applicable threshold (standard quality for $0.24 \mathrm{ppm} \mathrm{CH}_{4}, \mathrm{NO}_{2} 0.05 \mathrm{ppm}$ and dust 0.26, Table 2)

The research finding on water quality on the affected areas (outside the dike that was built) shows that it has changed physically and it smells and tastes bad. The content of dissolved solids such as iron, manganese, chloride, cadmium, potassium permanganate, $\mathrm{H}_{2} \mathrm{~S}$ and salinity exceeded the threshold level (PSKB, 2009). This hot mud causes soil pollution at the area around the blast / outside the dike. Soil contamination is caused by the spillage of hot mud (over-topping) from the gas blast.
The phenomenon has caused damage / death of some plants such as bananas, sugar cane and other crops in a radius of about 200 to 250 meters from the Periphery of the dike. Another result, which was felt by residents around the blast, was the health problem. The field data obtained in Porong Health Center (Puskesmas Porong) years from 2006 to 2007, there is an increase in cases of respiratory illness (Acute Respiratory Pipe Infection) of $62.5 \%$. The increase in cases of respiratory disease is suspected due to the HC gas pollution in the air that exceeded the threshold eligibility [24].

In conclusion, in terms of spatial planning, ecosystem, water quality, soil contamination, as well as the health problems, it is clear that changes in the structure of spatial has occured due to the results of the hot mud volcano flow. Therefore, due to the above phenomena, a new concept of spatial thinking in the specific affected areas need to be carried out.

\section{The Concept of Spatial Planning Scenarios}

Judging from the pre-existing Sidoarjo Regency Spatial Planning, it is necessary to revise the spatial development plan in the case of hot mud in Porong. This is absolutely made for the Sidoarjo Regency Spatial Planning 2003-2013, where there were no cases of hot mud volcano flow in Porong. The concept of dynamic growth of Sidoarjo Regency Spatial Planning 2009 -2029 is called 'triangle spatial development concept', known as SIBORIAN growth pole triangle development concept, which is already implemented in Sidoarjo Regency Spatial Planning 2003-2013 (Fig. 4).

One major thing remains questionable until today (i.e. due to different opinions among experts), is when and how this hot mud volcano flow can be stopped. In this context, spatial revisions are being made by the Government of Sidoarjo Regency. One of the things emphasized in the revision of this spatial planning is the carrying and environmental capacities of the region [3]. Analysis of capacity and carrying capacity of the land is based on consideration of environmental geology in the planning area [2]. Based on geological conditions of the environment, several elements can be used as resources (geological), which include ground water productivity, slope and geological engineering. The environmental geological conditions are categorized dangerous to lead soil movement vulnerability against earthquake. Several studies of hot mud volcano flow in Porong can be predicted to reduce land surface (land subsidence). The land subsidence can occur by vertical movement of mass towards the bottom, where changes occur under the ground, such as extraction of oil and natural gas. Downward vertical movement on the ground can also occur as a result of the load on the soil surface and the process of soil compaction. Land subsidence can happen gradually or suddenly (PSKB,2009). Based on satellite imagery of Singapore 2009 CRISP, the image area submerged in mud up to March 2009 is shown as below Results of spatial analysis using the overlay method (i.e. Fig. 8, 9, 10, 11) obtained by prediction affected area to the Lapindo hot mud volcano flow. Based on some of the above descriptions, whether it comes from research or taken from a concept of planning for the 
affected areas, the scenario of spatial planning is elaborated as the following.

\section{Scenario of Spatial Planning}

Spatial planning scenario is based on the provisions set forth in the Regulation number 26 of 2007 Article 26 paragraph (5) and Article 26 paragraph (6), where evaluation plan of the Regional Spatial Planning can be done at least one (once) every five year. Evaluating can be done more than once in case of special things such as large-scale natural disasters or other things such as changes in the boundary of state, province and region / district or territory specified Act. In the case of hot mud volcano in Porong, this disaster can be defined as geological and ecological hazard [4]. Environmental risks to human could be increased by poor location or design of land development [5]. Therefore, it is necessary to understand the impact of hot mud volcano in terms of 'hazard' and 'risk'. Hazard is the inherent danger associated with a potential problem and risk probability caused by that hazard [7]. According to the definition and the uncertainty of when the hot mud volcano flow is going to stop, the spatial planning should be divided into 3 schemes as follows:

\section{E. Short-Term: Scheme 1(1 to 5 years: form 2009 to 2014)}

Short-term planning scenarios are intended to anticipate the conditions when the hot mud volcano flow can be overcome or stopped naturally. The efforts are affected by planning the location of areas affected by the map input. Based on these predictions, the area to be affected by input is 875 hectares. This area in Sidoarjo Regency Spatial Planning (RTRW) 2009 - 2029 is designated as a 'geologic protected zone' (Kawasan Lindung Geologi). This means that any activity is not allowed in the area except those related to research activities about hot mud volcano flow.

Satellite images (i.e. Fig. 4, 5, 6, 7) showed the impact of hot mud volcano flow and the details are as follows:

1. Ring dike used as the direction of the mud has gone.

2. Dominant flow direction towards the east, north and a small portion to the west, to the dominant flow can be predicted to the east where the level of soil degradation occurs mainly in the Glagah Arum village.

3. In the south area of hot mud, there is a picture of a white solid area of land and the predicted increase in soil (uplift).

4. Hot mud volcano areas increased at about 875 hectares since the disaster occurred and more dominant to the east side.

In the framework of land-use planning, it is necessary to anticipate a wider area with a base of development that has occurred up to now. The use of the dike as a tool to localize the hot mud volcano flow happens only temporary if the mud continues to flow from the blast center. On the other hand, since the last 2 years there have been many new blasts (bubble) outside the dike area, which has grown bigger all the time. Areas with this new burst are needed to be considered as an affected area of the hot mud volcano flow in Porong. At the beginning of the feasibility study in 9 villages around the dike (2008), maps of feasibility settlements were produced, where there were only 3 villages worst affected among others (Siring Barat Village, Jatirejo Barat and Mindi). Based on the existing condition of the affected area (December 2009), it can be predicted that several other villages have got bad impact and needs further evaluation (radius of approximately $5 \mathrm{~km}$ from the center of the hot mud volcano flow).

\section{F. Medium-Term: Scheme 2 (5 to 10 years: from 2014 to 2019)}

Medium-term planning scenario is to designed to anticipate if in 5 years hot mud volcano could not have been stopped or overcome, the Sidoarjo Regency Spatial Planning would be developed under the bases of the prediction on affected area to area affected in the year 2019. Based on the prediction, the area to be affected until the year 2019 is approximately 1,200 hectares (assuming that the hot mud volcano flow would not have stopped with the volume of $100,000 \mathrm{~m}^{3}$ per day).

\section{G. Long - Term: Scheme 3 (10 to 20 years : from 2019} to 2029)

Long-term planning scenario is designedin case of the blast of hot mud that would not have stopped until the end of Sidoarjo Regency Spatial Planning (RTRW) 2009-2029. This is also in line with the experts saying that hot mud volcano flow can continue until about 30 years.

Scheme 3 is that the mud volcano is channeled to the wetland area. The location of this wetland area is adjacent to the east Porong District (bordering the straits of Madura) and the selected zone pond areas that become not productive. In order to implement this scheme, a more intensive academic study is needed, especially to determine how far the influence of wetland utilization on the environment, the optimal location, the area required, the implemented systems, and so on, which influence the structures and patterns in the Sidoarjo Regency.

\section{CONCLUSION}

Spatial Planning would notbe able to deny all hazards, but 'intelligent' location and design of structures and land uses could reduce the risks. According to the hot mud volcano disaster in Porong-Sidoarjo, an Integrated Spatial Planning (Integrated Development Planning) in affected area is urgently requireded. However, a specific factor in spatial planning, particularly in the areas affected by the hot mud volcano flow is a geological-ecological conditions, which has been decided in Sidoarjo Regency Spatial Planning 2009-2029 as 'Kawasan Lindung Geologi' (Geologic Protected Zone).

In conclusion, several important things related to the spatial planning (spatial structure), both in the region and in Sidoarjo hot mudflow affected areas are as follows:

1. Scenario for Sidoarjo Regency Spatial Planning is to establish the structure and patterns of space to accommodate the growth of local area (Sidoarjo Regency) and regional (regional development unit GERBANGKERTOSUSILA: Gresik, Bangkalan, Mojokerto, Surabaya, Lamongan Plus Pasuruan).

2. The concept of spatial arrangement for the hot mud volcano areas is a spatial dynamic model. The spatial dynamic means affected area can be replanned at any 
time when things are beyond prediction, and harmful to humans and the environment.

\section{SUGGESTION}

Reducing the worst impacts on societies (the emergence of casualties) should be considered as a priority. Monitoring and assessment are needed to be carried out every 6 months, both changes in the surface soil and the depth of the soil, so the appropriate action in the field can be considered and anticipated.

\section{REFERENCES}

[1] T. Beatley, and K. Manning, 1997, "The ecology of space: planning for environment, economy, and community", Island Press, Washington D.C.

[2] S. Campbell, and S. S. Fainstein, 2003, "Readings in planning theory(second edition)", Blackwell Publishing, USA.

[3] M. Kuncoro, 2002, "Analisis spasial dan regional: Studi aglomerasi dan kluster industri Indonesia", Unit Penerbit dan Percetakan AMP YKPN Jogyakarta.

[4] I. Moffat, 1995, "Sustainable development: Principles, analysis and policies", The Parthenon Publishing Group, New York, London.

[5] F. D. Muschett, 1997, "Principles of sustainable development", St. Lucie Press, Delray Beach, USA.

[6] Pusat Studi Kebumian dan Bencana (PSKB), Lembaga Penelitian dan Pengabdian Masyarakat Institut Teknologi Sepuluh Nopember, 2009, "Penanggulangan semburan lumpur Sidoarjo", ITS Press, Surabaya.

[7] J. Randolph, 2009, "Environmental land use planning and management", Island Press, Washington D.C.

[8] S. M. Rumbudi, H. Djunaidi, H. Wawan, 2007, "Penyelidikan tataan air tanah kabupaten Sidoarjo dan sekitarnya terkait terjadinya semburan lumpur", Badan Geologi Pusat Lingkungan Geologi, Departemen Energi dan Sumberdaya Mineral, Jakarta.

[9] H. Sulistyarso, T. Haryanto, 2009, "Tinjauan rencana tata ruang Kabupaten Sidoarjo akibat 3 tahun semburan lumpur panas Porong", presented at National Seminar: 3 Years Hot Mud
Volcano Eruption in Porong-Sidoarjo, Juli15 $5^{\text {th }}$ 2009, ITS, Surabaya.

[10] N. Taylor, 1998, Urban planning theory since 1945, SAGE Publications Ltd.,London.

[11] A. Tuti, 2008, "Laporan hasil survey semburan lumpur Sidoarjo", Unit Pengkajian Pengembangan Potensi Daerah, ITS, Surabaya.

[12] United Nations Environment Programme / UNEP,2006, "Awareness and preparedness for emergency at local level", National Workshop, March 28-29 ${ }^{\text {th }}$ 2006, ITS, Surabaya.

[13] A. Widodo, 2007, "Memahami bencana gunung lumpur (studi kasus lumpur Sidoarjo)", ITS Press, Surabaya.

\section{REGULATION}

[14] Undang-Undang Republik Indonesia Nomor 27 Tahun 2007 tentang Pengelolaan Wilayah Pesisir dan Pulau-Pulau Kecil.

[15] Undang-Undang Republik Indonesia Nomor 26 Tahun 2007 tentang Penataan Ruang

[16] Undang-Undang Republik Indonesia Nomor 24 Tahun 2007 tentang Penanggulangan Bencana.

[17] Undang-Undang Republik Indonesia Nomor 23 Tahun 1997 tentang Pengelolaan Lingkungan Hidup.

[18] Peraturan Pemerintah Nomor 16 Tahun 2004 tentang Penatagunaan Tanah.

[19] Keputusan Presiden Nomor 32 Tahun 1990 tentang Pengelolaan Kawasan Lindung.

[20] Keputusan Menteri Energi Sumber Daya Mineral Nomor 1457.K/20/MEM/2000 tentang Pedoman Teknis Pengelolaan Lingkungan di Bidang Pertambangan dan Energi.

[21] Peraturan Daerah Propinsi Jawa Timur Nomor 2 Tahun 2006 tentang Rencana Tata Ruang Wilayah Propinsi Jawa Timur.

[22] Peraturan Gubernur Jawa Timur Nomor 10 Tahun 2009 tentang Baku Mutu Udara Ambien dan Emisi Sumber Tidak Bergerak di Jawa Timur.

[23] Peraturan Gubernur Jawa Timur Nomor 39 Tahun 2008 tentang Baku Mutu Udara Ambien dan Emisi Sumber Tidak Bergerak di Jawa Timur.

[24] Peraturan Daerah Kabupaten Sidoarjo Nomor 6 Tahun 2009 tentang Rencana Tata Ruang Wilayah Kabupaten Sidoarjo Tahun 2009-2029.

[25] Peraturan Daerah Kabupaten Sidoarjo Nomor 16 Tahun 2003 tentang RencanaTata Ruang Wilayah Kabupaten Sidoarjo Tahun 2003-2013.

TABLE 1.

HC QUANTITIES IN SIRING BARAT, JATIREJO, AND MINDI

\begin{tabular}{ccc}
\hline No & Village & $\begin{array}{c}\text { Quantities } \\
\left(\mathrm{CH}_{4} / \text { methane }\right)\end{array}$ \\
\hline 1 & Siring Barat & $2182-5500 \mathrm{ppm}$ \\
2 & Jatirejo & $11350 \mathrm{ppm}$ \\
3 & Mindi & $22000 \mathrm{ppm}$ \\
\hline
\end{tabular}

Source: Center for Earth and Disaster Studies,LPPM ITS,2009

TABLE 2.

HC QuANTITIES IN SiRING BaRAT MEASURED WITH NO2 AND DUST

\begin{tabular}{cccc}
\hline $\begin{array}{c}\text { Village /air } \\
\text { pollution }\end{array}$ & $\begin{array}{c}\mathrm{CH}_{4} \\
(\mathrm{ppm})\end{array}$ & $\begin{array}{c}\mathrm{NO} 2 \\
(\mathrm{ppm})\end{array}$ & $\begin{array}{c}\text { Dust } \\
(\mathrm{ppm})\end{array}$ \\
\hline Siring Barat & $2182-5500$ & 0.116 & 0.351 \\
Standard Quality & 0.24 & 0.05 & 0.26 \\
\hline
\end{tabular}

Source : Center for Earth and Disaster Studies LPPM ITS,2009 


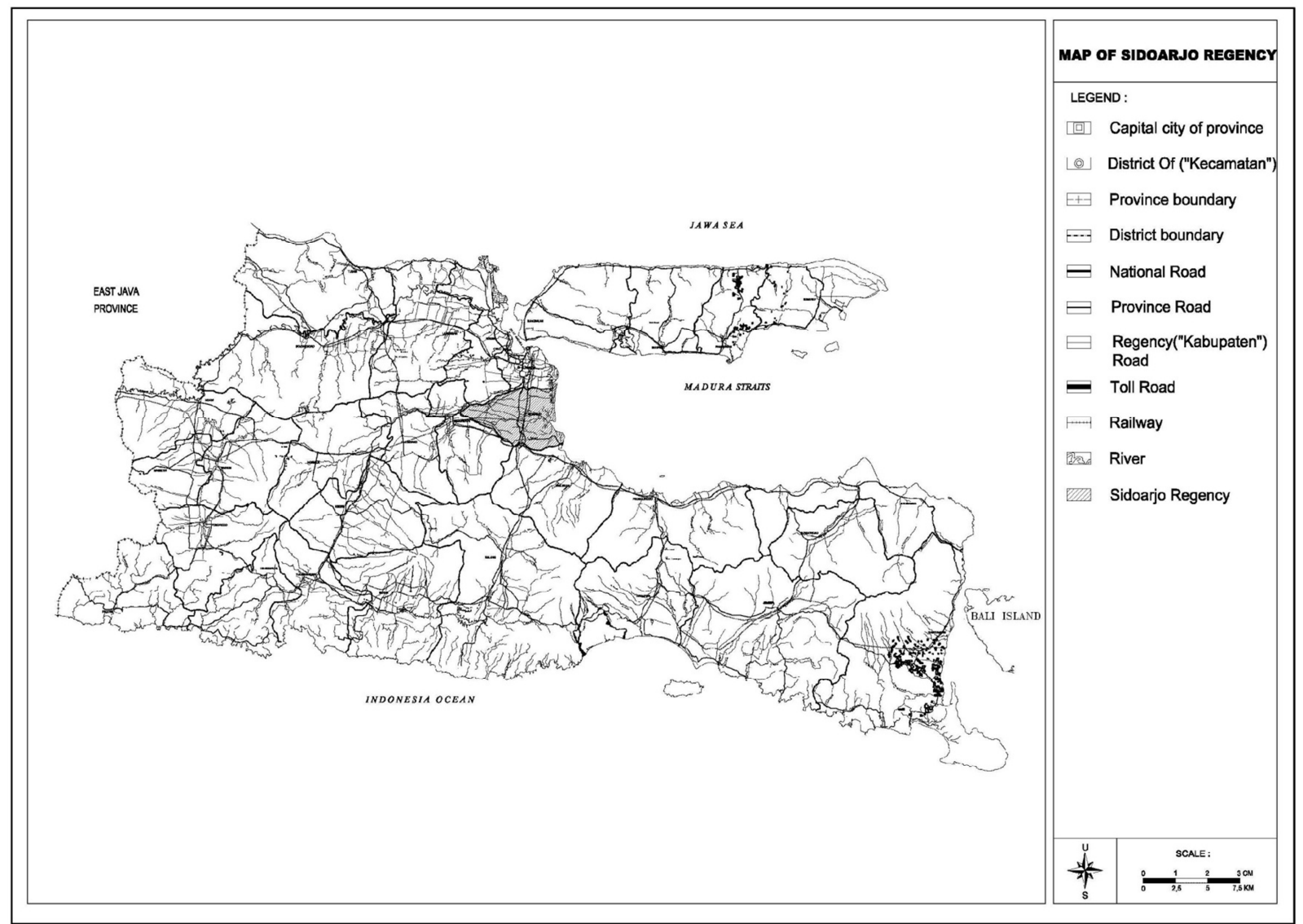

Fig. 1. Map of Sidoarjo regency source: ISidoarjo regency spatial planning 2009-2029

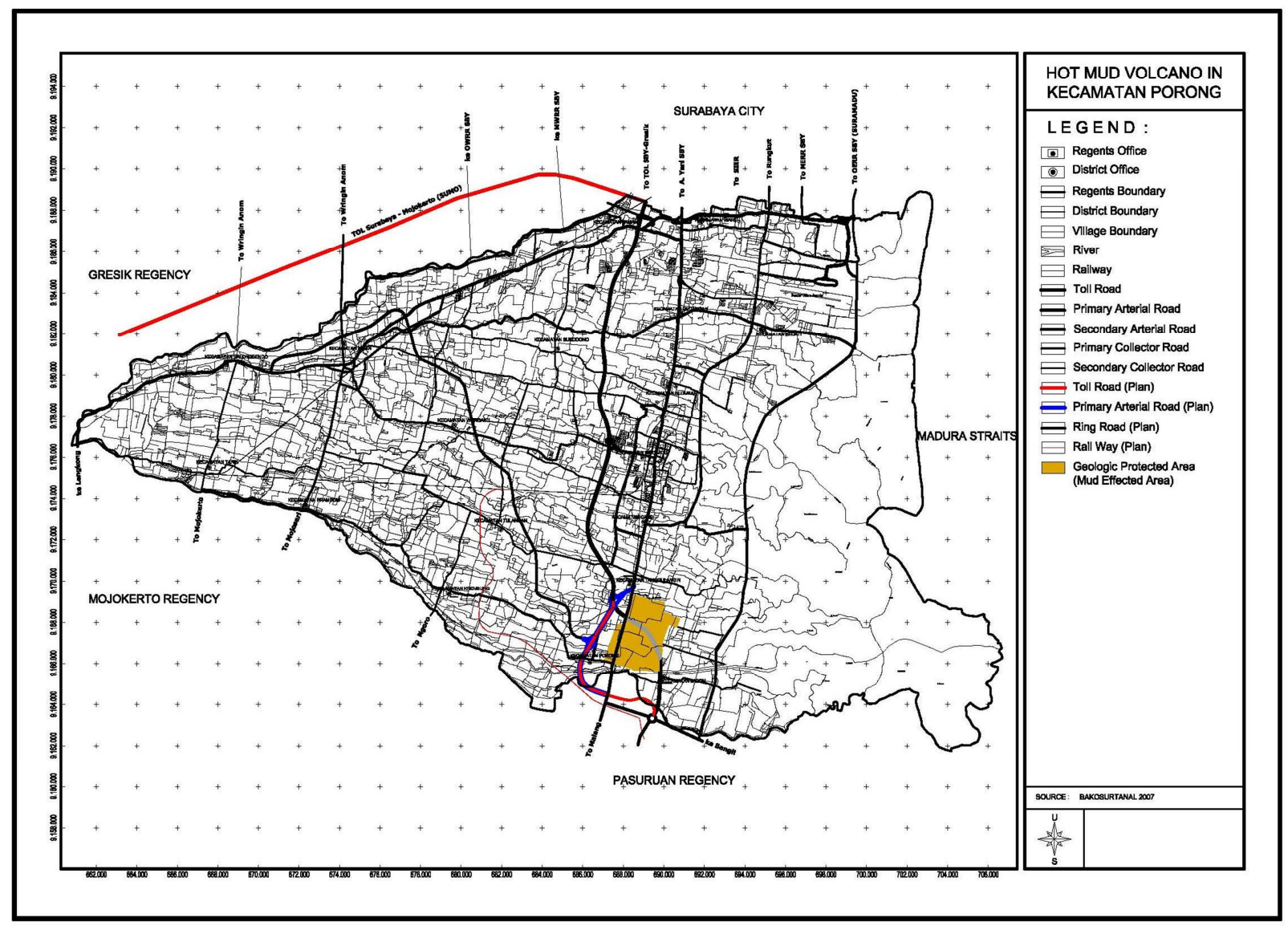

Fig. 2. Hot mud volcano in kecamatan Porong source: Sidoarjo regency spatial planning 2009-2029 


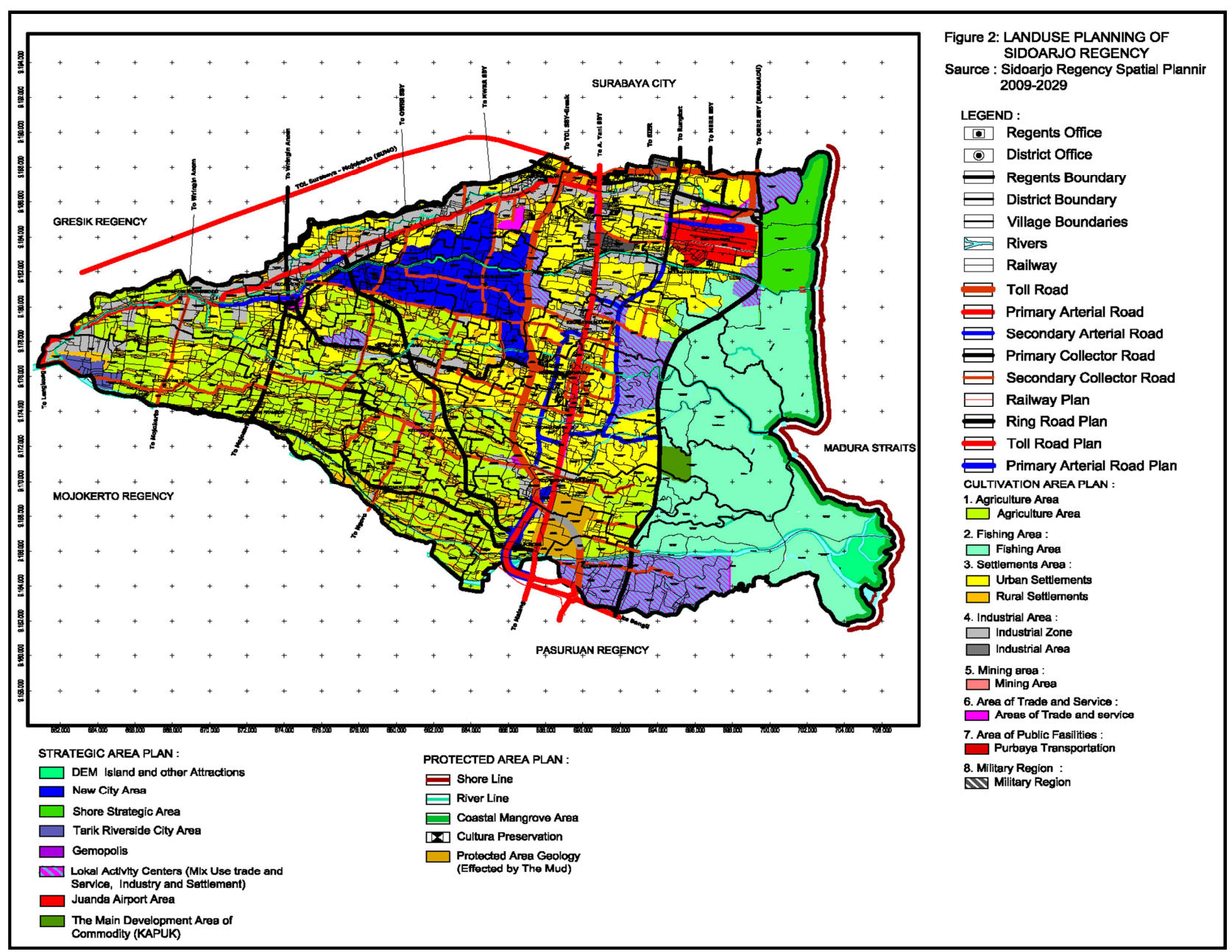

Fig. 3. Land use planning of Sidoarjo regency source: Sidoarjo regency spatial planning 2009-2029

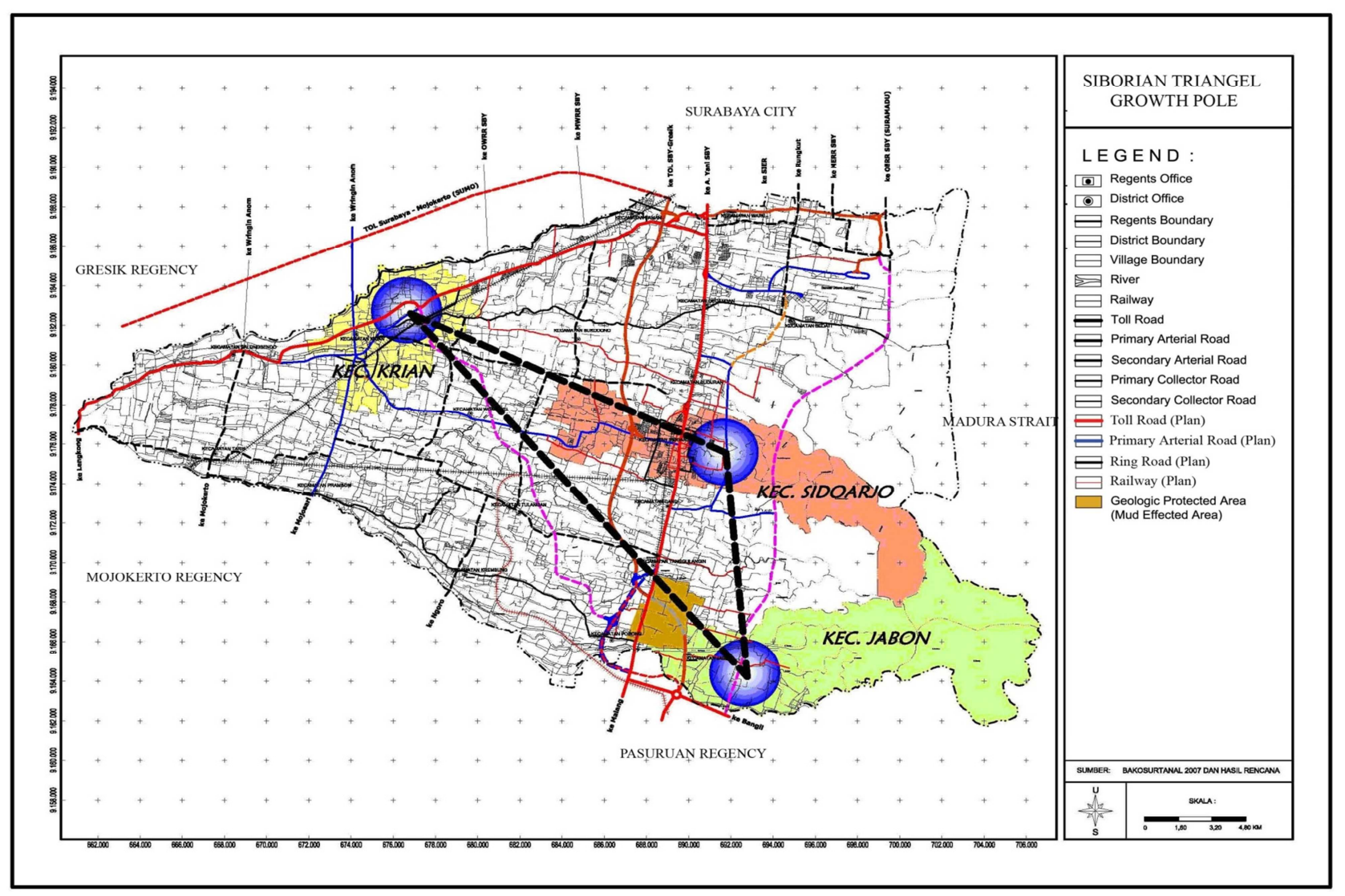

Fig. 4. SIBORIAN Triangle spatial development concept source: Sidoarjo regency spatial planning 2009-2029 


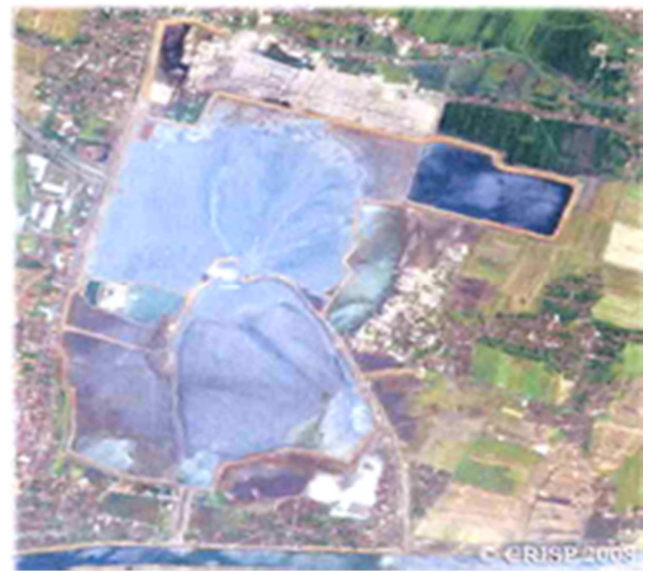

Fig. 5. Hot mud volcano area, October 2008

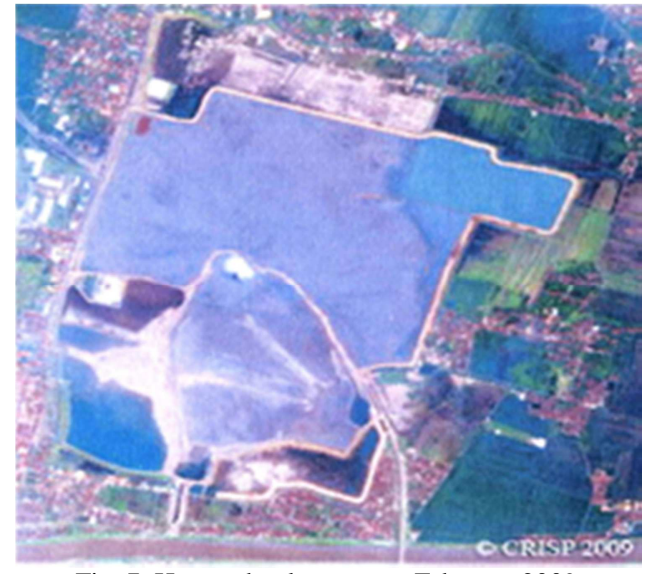

Fig. 7. Hot mud volcano area, February 2009

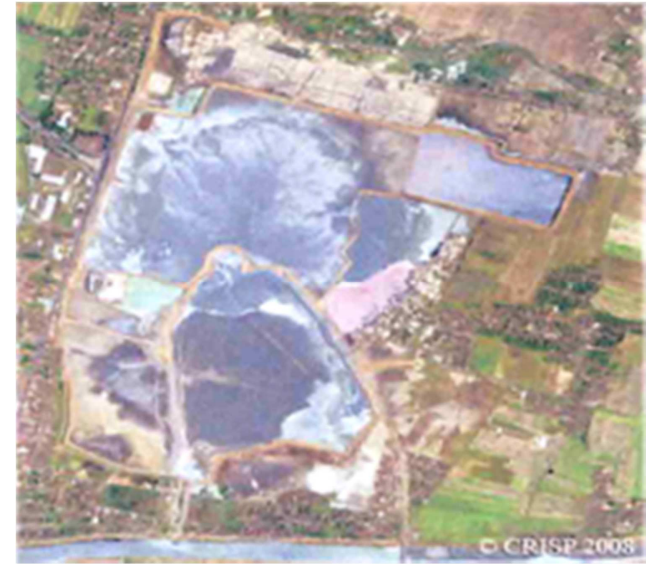

Fig. 6. Hot mud volcano area, November 2008

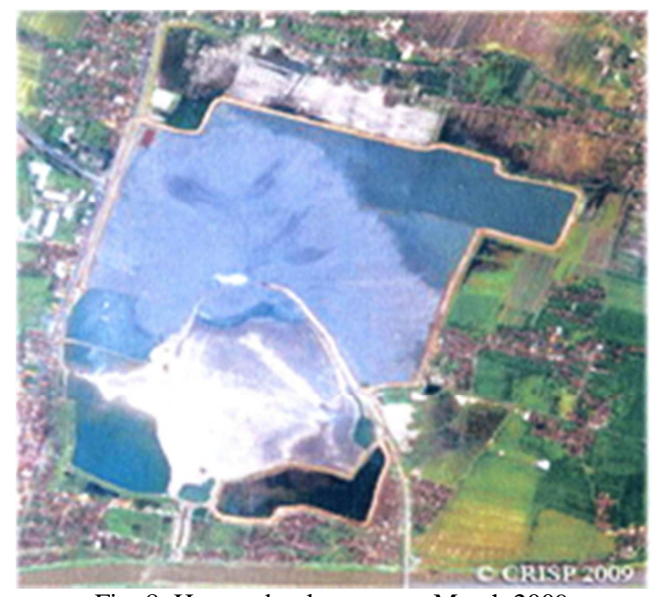

Fig. 8. Hot mud volcano area, March 2009

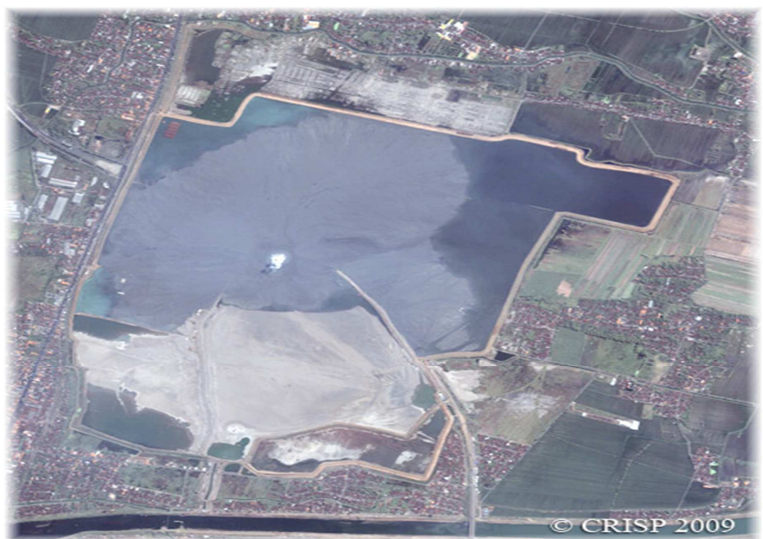

Source: CRIPS-Singapore

Fig. 9. Satellite image 26-06-2009 
IPTEK, The Journal for Technology and Science, Vol. 21, No. 3, August 2010

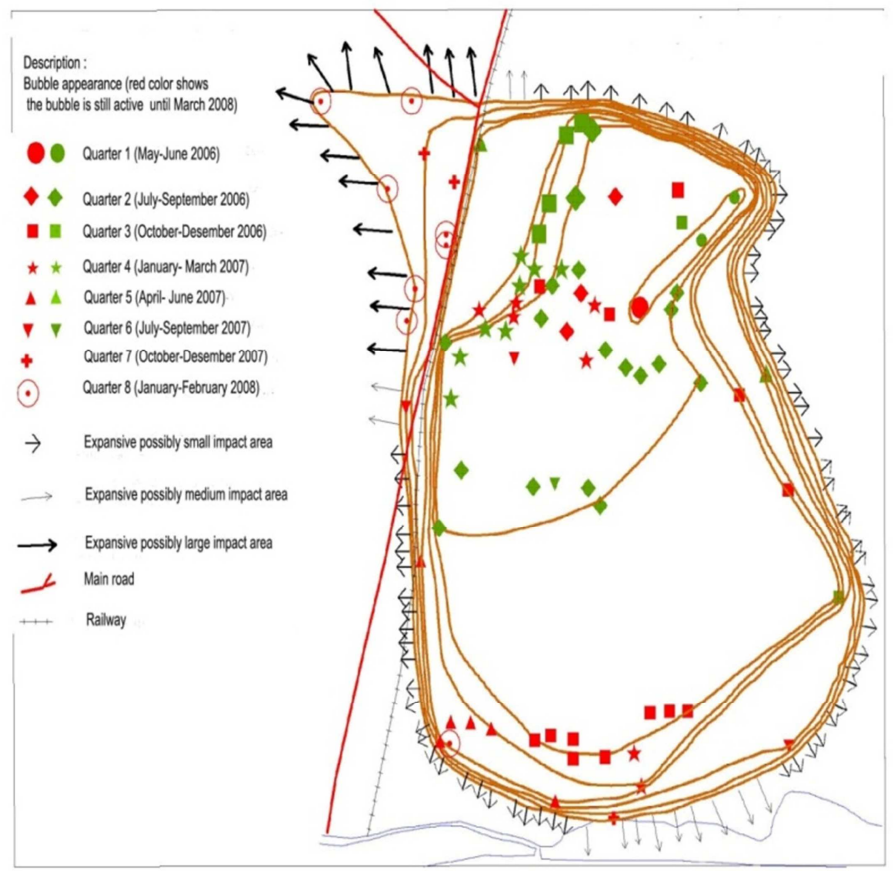

Fig. 8.Tendency of hot mud volcano flow

Source: Departemen Energi dan Sumberdaya Mineral, Pusat Lingkungan Geologi, Jakarta 2009

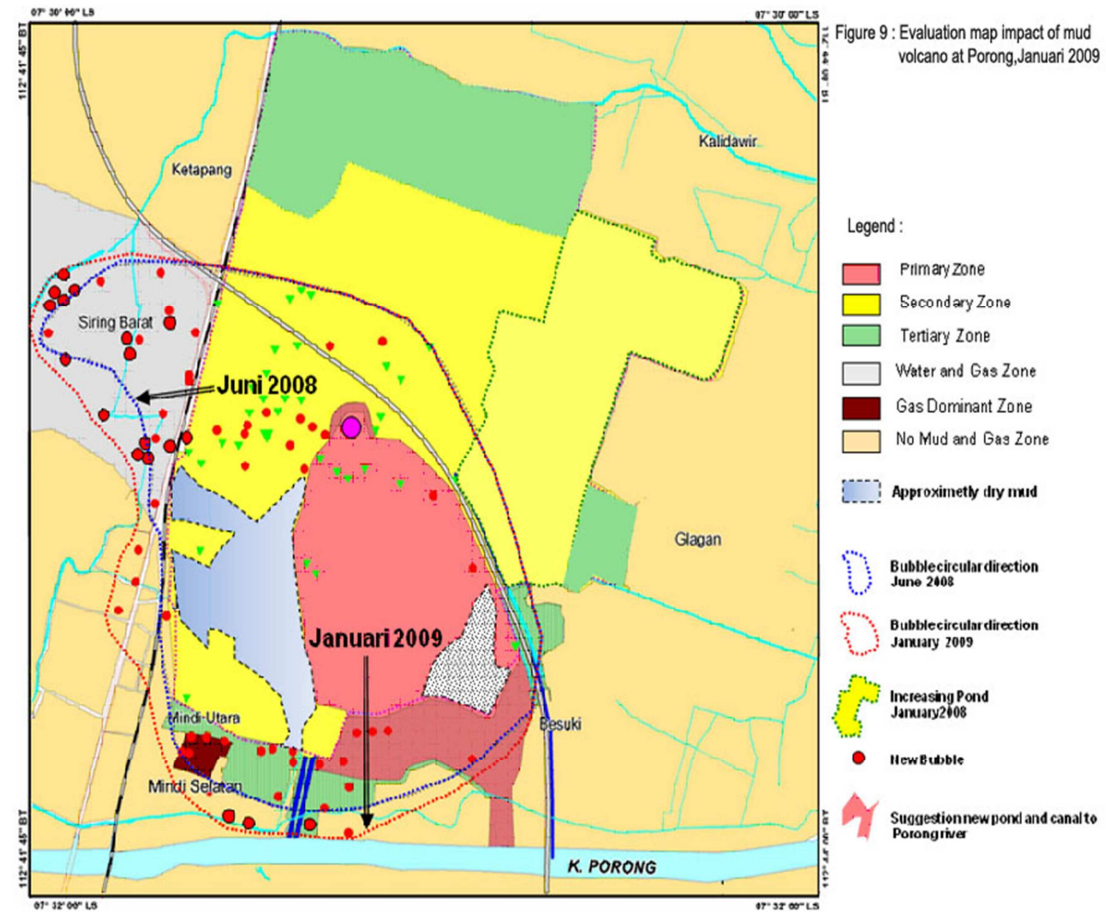

Fig. 9. Evaluation map impact of mud volcano at Porong, January 2009 


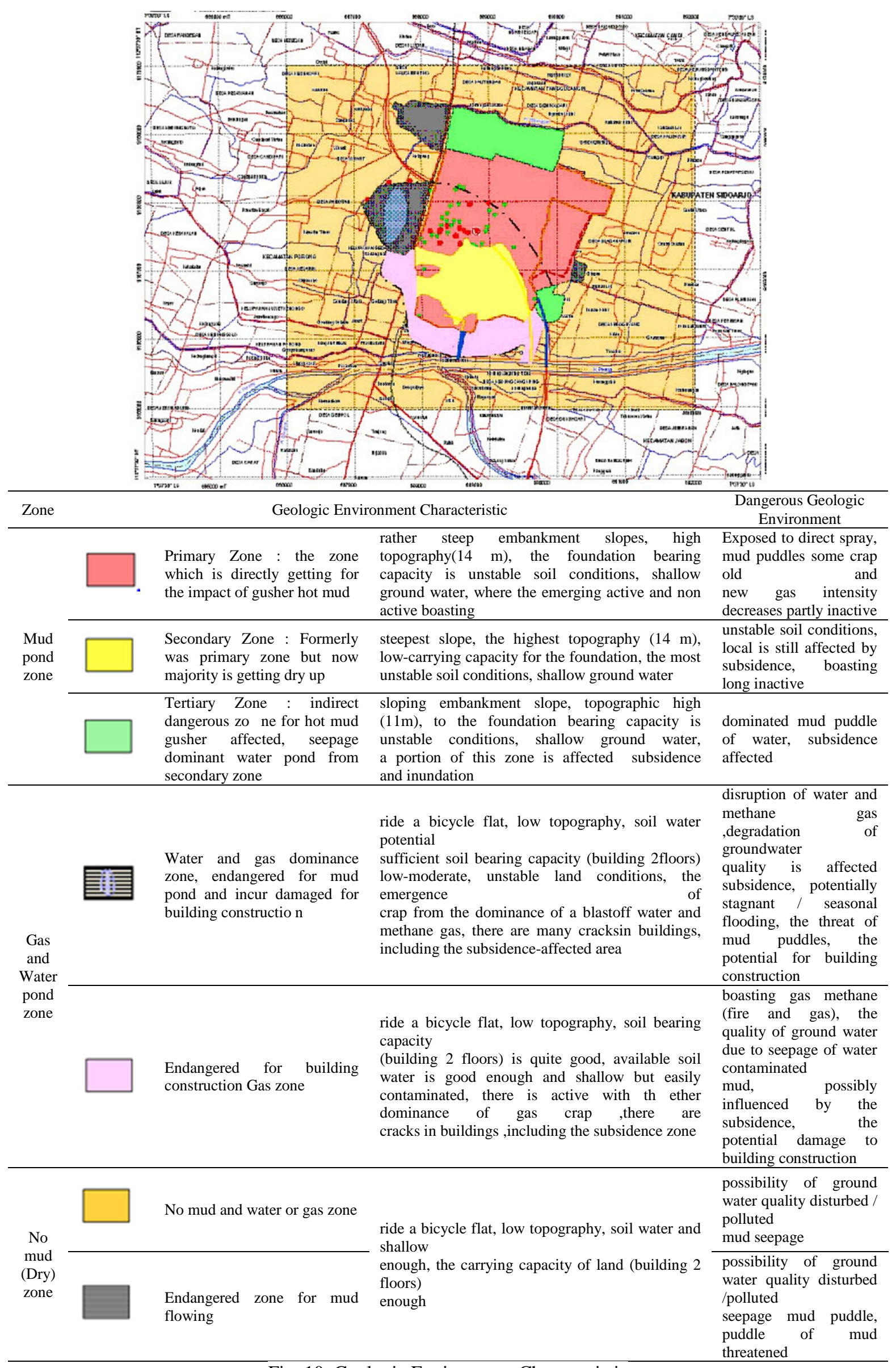

Fig. 10. Geologic Environment Characteristic

Source: Departemen Energi dan Sumberdaya Mineral, Badan Geologi, Pusat Lingkungan Geologi, Jakarta, 2009 


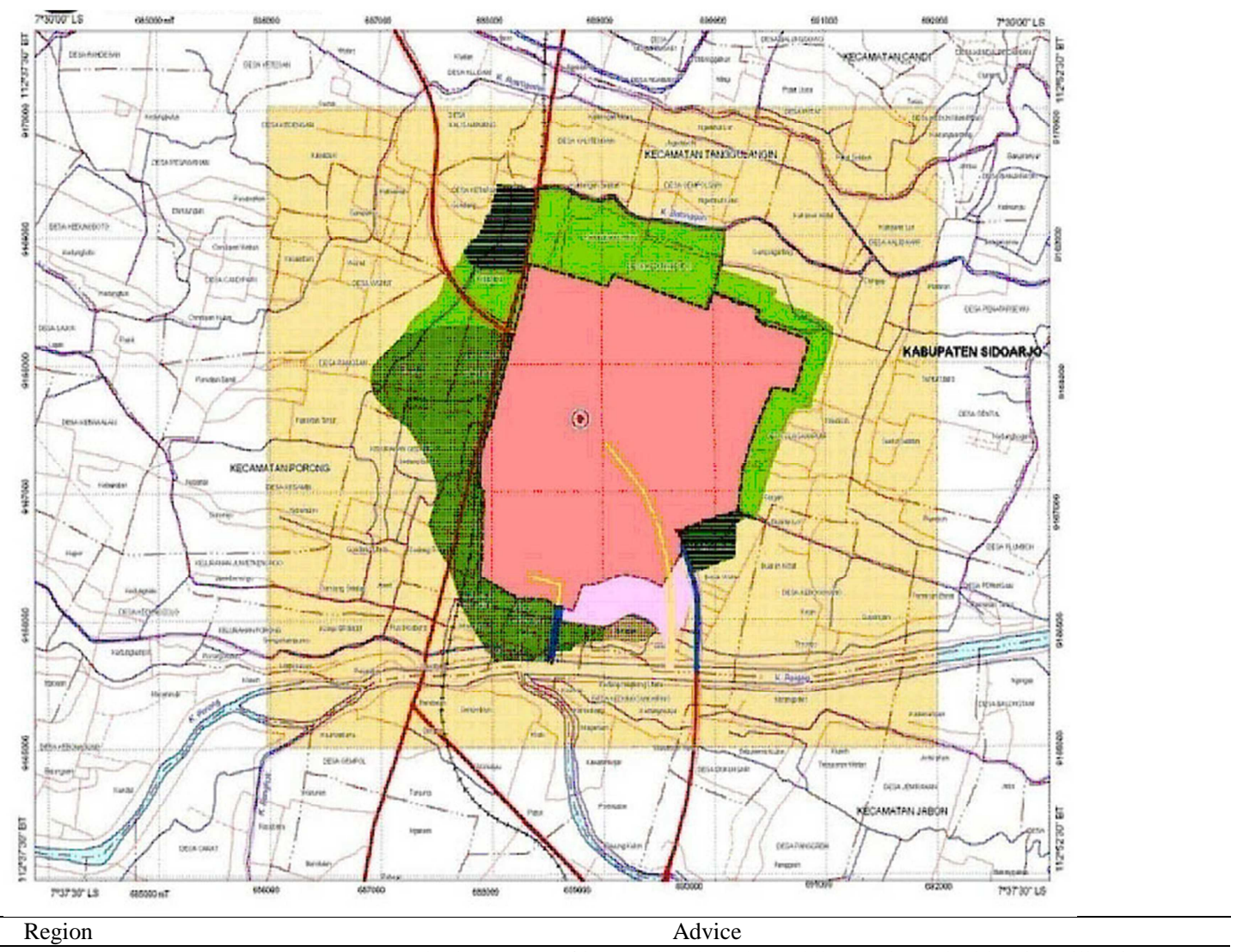

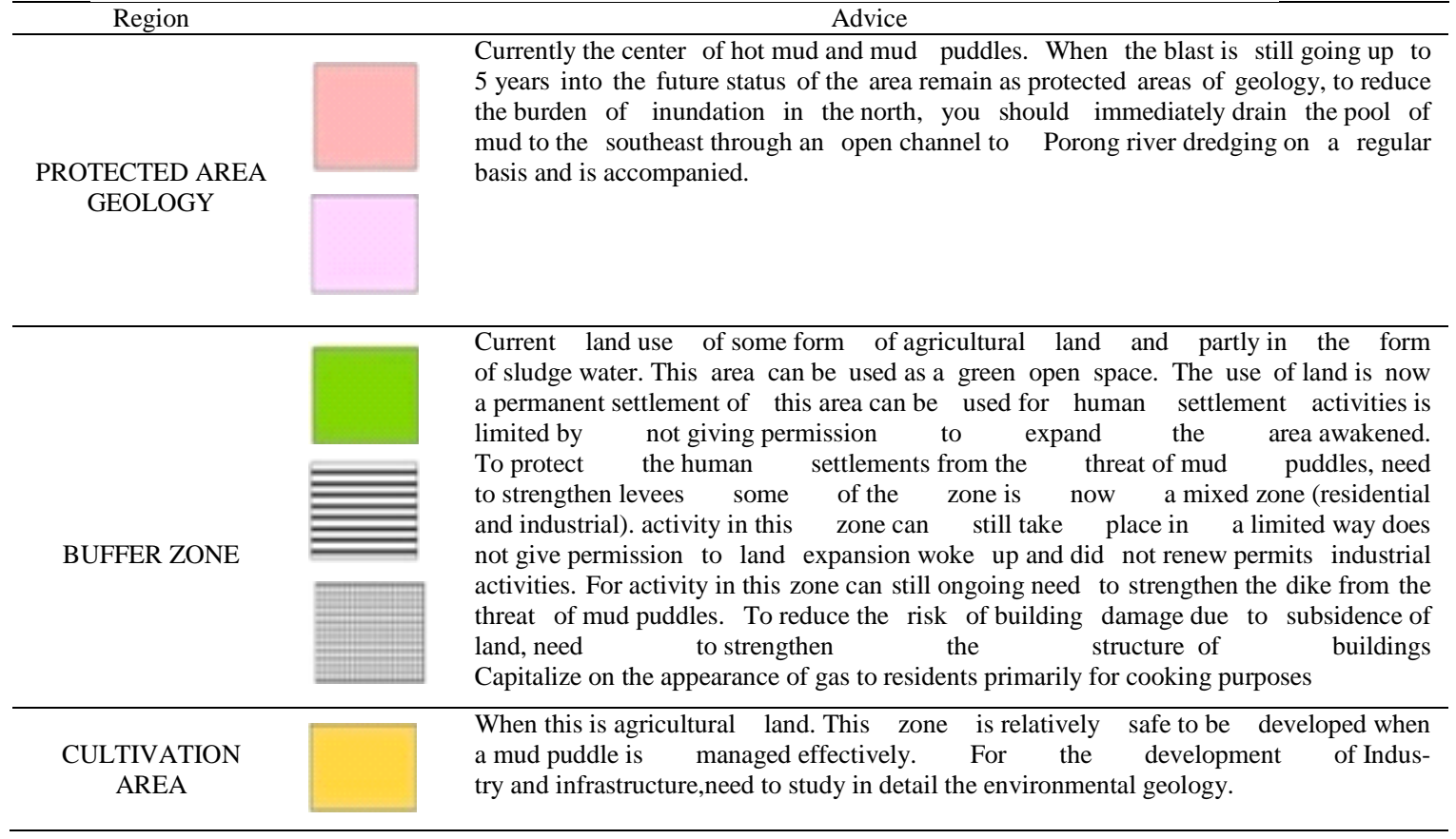

Fig. 11. Map of geologic protected zone 
IPTEK, The Journal for Technology and Science, Vol. 21, No. 3, August 2010 